\title{
Science education in pandemic times: what can we learn from COVID-19 on science technology and risk society
}

\author{
Maurício Pietrocola ${ }^{1,2}$ \\ mpietro@usp.br \\ https://orcid.org/0000-0003-1839-8005 \\ Ernani Rodrigues ${ }^{1, *}$ \\ ernanivr@gmail.com \\ https://orcid.org/0000-0003-3153-1085
}

Filipe Bercot ${ }^{2}$

bercot@ib.usp.br

https://orcid.org/0000-0002-4353-2774

Samuel Schnorr ${ }^{1}$

schnorr.sm@gmail.com

https://orcid.org/0000-0001-9326-1477

${ }^{1}$ School of Education, University of São Paulo, Brazil

${ }^{2}$ Institute of Advanced Studies, University of São Paulo, Brazil

*corresponding author

\begin{abstract}
The current COVID-19 pandemic raises reflection on the new roles of science education in citizen education in a world characterized by civilization risks, derived from the c socioeconomic development. This specific type of risk is treated as manufactured risk as proposed by the sociologist Ulrich Beck. In this work, we report a document analysis starting from Beck's risk society theory, followed by notions of reflexive modernity, risk perception and the Cynefin decision making model for complex problems. COVID-19 pandemic is characterized as a manufactured risk and we present features of it. We state that students are unable to deal with manufactured risk because of the type of problems they are usually prepared to solve at school and the limited risk perception they have. In order to acquire a better science education, we propose the integration of wicked problems in science programs alongside the use of a multidimensional schema, so-called amplified risk perception space, a tool to locate students' risk perception. We hope to contribute to prepare citizens for a world of global and complex events, such as the current pandemic.
\end{abstract}

Keywords: Citizenship education. Complex problems. COVID-19 pandemic. Manufactured risk. Risk perception. Risk society.

\section{Introduction}


The pandemic caused by Sars-CoV-2 virus is spread all over the world and have been unveiling people's difficulty in dealing with health orientations in order to make decisions about better conduct. From policy makers to entrepreneurs, liberal professionals or workers, there seems to be no distinction regarding the diffuse perception of threats and the difficulties on decision making. A scenario of uncertainty has cast a veil over reality, obscuring short, medium and long-term views. Certainties collapsed along with part of our rationality. It seems clear that, in the middle of the pandemic, there is a gap in the so-called critical and active citizenship. Beyond fears of death pandemic revealed individual and collective lack of ability to rationally deal with situations imbued with uncertainties.

Apparently there is a blind spot in science education leaving society to see itself helpless when facing pandemic, which enacts important reflections for the science educators community. Once we advocate for scientific literacy as the basis for exerting critical citizenship, we must find ways to act wisely and balanced by accessing science and technology knowledge. Regarding science education, Derek Hodson argues that it must go beyond teaching how to competently solve problems ("teaching science") including teaching how science is produced and what are the uses of science (Hodson 1992; 2011). The tripod proposed by Hodson soon became a science education agenda, seen in the "scientific and technological literacy" metaphor (Vesterinen et al. 2016). Grounded in different dimensions of knowledge, science takes place as a reliable source, capable of giving explanations and guide problem solving of several kinds (Aikenhead 2006).

Nowadays, however, science primacy faces a contrast: overreactions, shallow interpretations and hasty causal relations popping out refer back to pre-enlightenment times, as rationality loses its place. Despite countless expressions of solidarity worldwide, we can not yet determine which one will prevail between, on the one hand, the "save yourself if you can" instinct, inherited from our prehistoric ancestors, or, on the other hand, supportive attitudes capable of coordinating collective actions of mutual aid.

Questioning the roles played by science and technology in globalization and its impact on social life is a necessary anchor point in this reflection. As science and technology progress, everyone is placed on a social life contour which the edges no one can fully understand. Each new scientific discovery and/or each new technological application promote a multitude of possible futures on which we lack (or maybe abound) opinions grounded in science, making it increasingly difficult to make decisions in view of the inherent uncertainties.

A diffuse feeling of insecurity pervades people's minds. Notwithstanding the benefits developed by science and technology, people feel more vulnerable and exposed to more risks (Douglas 1994). Contemporary times have witnessed an increase in public anxiety and fragile confidence in science (Giddens 1990). Risks can trigger people's anxiety once they demand decision making involving imponderable and immeasurable factors which cannot be reduced to zero neither by previous experiences nor resorting to experts. That tension is stressed by the United Kingdom Select Committee on Science and Technology: "When science and society cross swords, it is often over the question of risk" (House of Lords 2000) 
Risk situations are characteristic of today's industrial society which does not produce only "goods" but also "bads" (Beck et al. 2013). Pollution, nuclear disputes, global warming, side effects in medical treatments, among others, are afflictions experienced by today's people as a result from the ways in which post-industrial society works. Market system can have both positive and negative effects on the environment, health and welfare (Hsu 2011). The COVID-19 pandemic, which started in Wuhan province in China and spread globally, can be framed as one of these consequences. The globalization of production and market figure a world as a complex system of interaction between different countries participating in the global value chain (Alves et al. 2019). That implies an intense mobility of products and people, something related to the virus spread (Kraemer et al. 2020; Buckee et al. 2020). In a certain way, people's feeling of insecurity, even though living in a supposedly safer world (at least for the ones who live in industrialized and wealthy regions) is a price to pay. From time to time, the bill is collected (in a pandemic, for example) by abruptly slowing everything down.

For Ulrich Beck, we are living in a Risk Society (Beck 1992). It emerges in the post-war and is characterized as an age of Reflexive Modernity (Beck, Giddens and Lash 1994). In this kind of modernity, central concerns of society have changed from developing and implementing new technologies to managing risks associated with already existing technologies. That means threatens and dangers are not only external but instead generated as unfolding of internal actions in society. Currently perception of risks has had a fundamentally transformative impact (Douglas and Wildavsky 1983). In this sense, Beck (1992) suggests that institutions are destabilized by the risks, caused by human action itself.

In another work, Beck (1999) writes, almost prophetically, that global cosmopolitanism world would be in check. In Beck's elaboration, a notion that world problems would no longer be localized in time and space, affecting everyone, would start to circulate within people's common sense. This notion has practical implications in risk perception. Risks such as global warming, pollution and, currently, COVID-19 pandemic, belong to everyone. However, the way it is shared and its management are asymmetrically distributed. Pandemic consequences tend to be different for a Los Angeles citizen, in the United States, compared to a Guayaquil citizen in Ecuador, for example. Beck alerts that global risks scenarios promote a pressure against nascent cosmopolitanism in favor of the "me first" selfish position. That can be seen in countries' attitudes, such as border closings and fights over masks (BBC 2020), or mechanical ventilators (Embury-Dennis 2020). These behaviors, according to Beck, are reflections of the surviving instinct. When decision makers face global problems, solutions tend to point to immediate threats. Each reader is able to fit this survival instinct to local situations regarding COVID-19 pandemic.

Jacques Delors' report (2010) states clearly that giving the means of access to conscious and active citizenship (only possible in democratic states) is the goal of XXI century education. There is a need for elements in science education that support a new agency in contemporary society in order to oppose traditional perspectives on citizenship (Kreuger and Ramos 2017). Modern discourse on citizenship is still in place, however we must take into account that the 
current context is marked by a State-nation crisis against globalization (Hall 1992). This means a context which includes local and global factors, such as global economy and globally spread information as well as communities of defense of local interests.

Focusing in the necessity of building a new understanding on what citizenship would be like, Westheimer and Kahne (2004) discuss its concept, once it has implications for school curricula. In doing so, they propose three categories embracing main arguments for answering the question "what kind of citizenship": (i) personally responsible citizen, in which personal attitudes, such as being honest and responsible, would lead to solving society problems; (ii) participatory citizen, where individuals taking leadership positions within established systems would lead to solving society problems and (iii) the justice-oriented citizen, in which society problems would be solved by questioning, debating and changing established systems and structures that reproduce patterns of injustice over time. Although the last one is least commonly pursued, that would be the more adequate to deal with contemporary global challenges.

Science contributes to many collective and individual decisions. Controversially, people often do not participate in decision making processes, being subject to deliberation made by experts (Jenkins 2000). This is pointed as an issue in a society seeking for effective and democratic participation from its citizens, especially considering that knowledge is tightly attached to power relations and social control (Wilkinson 2001).

Thus, it is urgent to take pandemic as an opportunity to reflect on today's science education. Questions remaining on this matter are: What is, after all, a citizenship for actual times? How should science education be oriented in order to exert a citizenship for justice? What are the objects of knowledge in this case? Some previous work in science education shed light over this issue. The "risk" subject became part of science curricula and educational programs (Levinson et al. 2012). In the Nuffield Report, on school science education Millar and Osborne (1998) made considerations bridging science and risk:

"By considering some current issues involving the application of science, pupils should . . . understand the ideas of probability and risk; be aware of the range of factors which can influence people's willingness to accept specific risks [...].” (p. 2022, highlight added)

Teaching units on risk assessment in science education can be seen in recent curricula. The Science Education for Public Understanding Program (SEPUP 2018) includes unities on decision making, probability and risk perception for 6-12 years old students; The National Curriculum for England (England 2014) proposes learning unities on risk assessment and a Core Science course for 15-16 years old students in the Twenty-first Century Science Curriculum (Millar 2006); also the Australian Curriculum, Assessment and Reporting Authority (Australia 2014) with teaching and learning activities for risk and security.

Yet, those examples seem to be exceptions as, mainly, countries are far from incorporating risks aspects as curricular themes (Christensen 2009). Kolstø (2001), as expatiates on socioscientific dilemmas, shows that students question risk assessment sources and their 
trusty relation on scientist intentions. Christensen (2009) argues that students' analysis are weakly grounded in their science knowledge or their understanding about the problem in place when they make risk assessment and points the lack of research in this sense "[...] little research has yet focused on students' understanding of risk or the role that risk might play in decision making on contemporary issues in science classrooms." (2009, p. 212). Levinson and colleagues (2012) can be taken as a spare exemplar of research focused on risk and its origins in complex relations between science and technology. They discuss the nature of risks and decision making in dilemma situations. However, they are taking the teacher's perspective, not the student's learning process.

Although the enormous importance of these works in the development of theoretical frameworks and methodological protocols, allowing to consider risks as an object of research, the mainstream approach seems to focus on sources of students' beliefs in order to assess risks. Of course this an important aspect of decision making, once sources of certainty are inadequate grounds to deal with risks. Thus, it is important to be able to understand that in reflective modernity, science and technology knowledge are, at the same time, sources of solution and sources of the problem, as proposed by Beck.

There is a double nature of risk: it has the objective facet, surrounded by technical knowledge, but it also has a subjective facet, surrounded by values (Schenk et al. 2019). This double nature imposes challenges for science education. As themes related to risk are approached, we must consider its inherent complexity and the countless variables enrolled, which directly and indirectly influences the problem. In a risk situation, simplistic causal relations, readily taking few available elements in the account, must be avoided because "real world" complexity demands more than that (Hansen and Hammann 2017). The idea of scientific knowledge authority as a reliable and secure source must be taken in a different nuance. In the risk society, trust does not arise from precision and authority. Instead it comes from the ability to perceive multidimensionality in different contexts and producing adjusts on the go (Christensen 2009).

With that said, this work aims to contribute to these reflections by offering some reorientation elements for a new kind of Scientific Literacy for a Risk Society, considering the pandemic scenario.

\section{Risk society and the new modernity}

Ulrich Beck became prominent in the beginning of the 90's through his work "Risk Society" where he analyses western society considering environmental risks. Before being translated to English in 1992, his book sold over sixty thousand copies in Germany. Since then, it has been translated to more than 35 languages (Mythen 2018). He connected institutional change and its daily micro-political challenges in fields such health, economy and (Sørensen 2017) environment. Environmental risks, Beck argues, promote important changes in society, especially air pollution and radioactive contamination. Growing risks of this kind stimulated 
resulted in a disproportionate increase in people's perception, changing their beliefs, their interests and their behavior.

Beck explores the risk concept by showing its deep impact in changes of contemporary society and its power for characterizing contemporary social order (Mendelson 2010). In Beck's sense, post-war emerging society is characterized by production of risk and burdens derived from technology, such as pollution, nuclear waste, global warming, and the side effects of medical treatment (Beck 1992).

Prior to Beck's work, Mary Douglas produced a solid work on risk through a cultural approach. In her terms, changing in economy and environment, as consequences of introduction of new technologies and globalization, has imposed questionings to current norms, values and traditions. That resulted in a condition of insecurity and uncertainty (Douglas 1994). Insecurity and uncertainty are cultural constructs and they lean on subjective judgment people make on the world where they leave. In her book Purity and Danger (Douglas 1966) she wrote:

"[...] whatever we perceive is organized into patterns for which we the perceivers are largely responsible. [...] As perceivers we select from all the stimuli falling on our senses only those which interest us, and our interests are governed by a pattern-making tendency, sometimes called a schema. In a chaos of shifting impressions, each of us constructs a stable world in which objects have recognizable shapes, are located in depth and have permanence. [...] As time goes on and experience builds up, we make greater investment in our systems of labels. So a conservative bias is built in. It gives us confidence." (Douglas 1996, p. 37-38)

Losing ontological security about the world is a consequence of our awareness on risks present in peoples reference frameworks. Today, risks are difficult to perceive due to the speed of events, the invisibility of threats or the appearance of new risks. Thus, individuals have their lives constrained by risks sometimes real but invisible other times even unreal (Giddens 1991). Climate change, global warming, forest fires, environmental accidents and pandemics are examples of those risks. People interact with those issues, both in a local and in a global scale (Giulio et al. 2015)

In discussion on contemporary social order, Beck's contribution is the proposal of a macrotheoretical sociology focused on nature-society interaction. Three of his works are emblematic in this sense: Risk Society: Towards a New Modernity (1992), Ecological Politics In A Age Of Risk (1995) and World Risk Society (1999). His thesis states that industrial society, anchored in scientific and technological knowledge, started to produce threatening situations. In a risk society, catastrophic situations are no longer an exception; they are the normality. Another aspect Beck's stresses is that "Risk societies are not class societies - that is not saying enough. They contain within themselves a grass-roots developmental dynamics that destroys boundaries, through which the people are forced together in the uniform position of civilization's self-endangering” (Beck 1992, p. 47).

At a first glance, we can ask whether, in a new world order, risks have actually increased or 
whether it is just a matter of public perception. This distinction does not make sense in Beck's proposal once "both sides converge, conditions each other, strengthen each other, and because risks as risks in knowledge, perceptions of risks and risks are not different things, but on and the same" (Beck 1992, p. 55).

In a risk society perspective, borders separating perception and facts about risks will be blurred. That because emerging risks are produced by society. Therefore, society members are responsible for them. This is what Giddens (1999) defines as being manufactured risks. Beck argues that today's risks do not need natural threat as buckets of causal factors and there is no way to find out a proper satisfactory actions: "Unlike demands, risks can be more than just called forth [...], prolonged in conforming to sales needs, and in short: manipulated [...] as the reference point of commodity production is taken over by the self-productible risks" (Beck 1992, p. 56).

Ulrich Beck, in collaboration with Anthony Giddens and Scott Lash (Beck, Giddens and Lash 1994), puts risk society as a result of a reflexive modernization. "Reflexive" would be a late stage of modernization, or a post-industrial modernization. In risk society, the danger-safety pair is replaced by a risk-trust relation. From that, two fundamental changes occur, both influenced by science and technology: the end of nature and the end of tradition. First, nature is no longer a dimension external to society; is no longer a source of threat. But it is integrated into the triad nature-society-technoscience. Nature's existence is as threatened as ours. Secondly, by the end of tradition, they mean the past is no longer a safe source of experiences for orienting our actions in the present.

It is worth to stress that science and technology are central in Beck, Giddens, and other adepts to risk society theory. Daniel Mendelson points out, societies draw on scientific and technological knowledge for structuring their advances: "organizing techniques of society are continually assessed to allow for reform and proper utilization of the knowledge available in a technologically advanced culture" (Mendelson 2011, p. 231).

As scientific knowledge (lato sensu) is central in modern and late modern societies, there are some specific categories socially constrained for identifying risks. In pre-modern societies, even in the apex of modernization, identifying risks did not demand specialized knowledge, being clear what would be a natural risk, such as a storm, or a social risk, such as being unemployed. Current risks are not those ones. Most of today's risks are hidden for most people, just like COVID-19 pandemic. In most manufactured risks scenarios, when a threat is perceived it is already materialized as danger, carrying potentially irreversible consequences. Thus, in order to deal with science dependence of late modernity risks, we must consider that threats are risks defined and formatted by specialists.

Giddens distinguish between external and manufactured risks. The former are events affecting individuals and groups, but generated from outside of modern social life; they are relatively regular and periodic, allowing one to predict its occurrence and being, therefore, insurable. The late are risks generated by progress of humankind social development, particularly through science and technology progressing, they take place in new danger 
environment for which history has provided us with very little prior experience, such as terrorism, Ozone depletion and so on.

Both Beck and Giddens argue that science and technology produce new uncertainties and new risks to society. Facing manufactured risks, science productions are recognized as something to be managed in perception and in decision making (Beck at al. 2013; Giddens 1990). Risk society, on the one hand, specialized knowledge, mostly scientific, plays a central role. Intensive use of scientific and technological knowledge has changed risks ontological profile. As risks are ingrained in society, civilization's previous approach to anti-risks fails. Now, we need science and technology for perceiving risks. According to Beck (1992), growing public spending for environment conservation and for fighting civilizing catastrophes as well as emergence of economic fields dedicated to risks show a first order economic development. Bring risks produced by the current model of society promotes a scientification of risks in a new risk market. Thus, the same economic system who promotes risks to society is the system that offers solutions and makes profit from it.

Ways for perceiving risks are aspects that must be taken into account in order to rethink science education in reflexive modernity. When excess wealth outweighs excess risk, it's important to deal with risk and its perception. If before a rational frame could distinguish between "science determining risks" and "people perceiving risks" this is no longer true. This share of responsibility was broken without a loss of rationality and without a technophobia. Instead, what it lost was a clear distinction between lay people and experts. Risks don't address anymore only to (and therefore are no longer managed by) experts. Neither to a multidisciplinary group of experts. Beck adds that this apparent irrationality blurs the focus of public perception, which can be interpreted as a lack of technical information. But "even in their highly mathematical or technical garb, statements on risks contain statements of the type that is how we want to live - statements, that is, to which the natural and engineering sciences alone can provide answer only by overstepping the bounds of their disciplines" (Beck 1992, p. 58).

It seems to be a balance between experts and others' way of seeing the world. That would balance what Beck calls "statements of how we want to live". Producing a balanced perception of risks is an essential factor for risk society. This is partially derived from the marked performance of natural sciences in defining risks (Beck 1992).

There would be an inversion in the relation between science and society: "The distinction between (rational) determination of risks and the irrational perception of them also inverts the role of scientific and social rationality in the origin of a civilizational risk consciousness." (Beck 1992, p. 58).

Codetermination in perception of risks, manufactured inside society, is also an important point. Both the inversion in scientific and social rationalities and the impossibility of taking them apart, have implications for the process of decision making. Manufactured risks involve a particular way of decision making because they start from premises very different, in time and space dimensions, compared to ordinary decisions: 
"...all decisions and hazard of civilizations falling within the compass of knowledge production are never just question of substances of knowledge (inquiries, hypothesis, methods, procedures, acceptable values, etc.). They are at the same time also decision on who is afflicted, the extent and type of hazard, the elements of the threat, the population concerned, delayed effects, measures to be taken, those responsibles, and claims for compensation.” (Beck 1992, p. 54)

The second point would be how to define what a problem situation is. A science education for risk implies in developing citizen formation using complex threats situations that take global conditions but at the same time can be felt locally (Christensen 2009). Understanding relations in a society, marked by complexity and uncertainties favors our recognition of unpredictable threats of manufactured risks. In a contemporary society of complexities and uncertainties, science became more and more contested by the public, an uncommon position for the field that has been always positioned as the answer holder for society yearnings (Barry and Ferracioli 2016).

We understand that science education, by working on manufactured risks situations, amplifies the teaching possibilities, including situations for contemporary real world problem solving, considering complex scenarios and its data and evidence available. This perspective can impact imprecise perceptions lay people built on "goods" and "bads" of scientific production, helping them to define their attitudes towards science and technology and its uncertainties of these days.

Uncertain situations containing manufactured risks refer to a different kind of problems, socalled "wicked" (Rittel and Webber 1973). Wicked problems don't allow definitive or secure answers not even given by experts. They contain tacit variables, hard to recognize, and they are marked by contradictions. A particular kind of knowledge must be enacted in order to convert unpredictable risks into computed ones. Those wicked problems can be reasoned under risk perspective, promoting the development of decision making competences by including multidimensional approach, from epistemological, psychological, sociological, cultural and pedagogical aspects (Ratcliffe and Grace 2003). We will be back to this point in section 4.

This is the context in which we understand that, for dealing with risks, a particular kind of ontological attitude must be developed, once different not-being entities are currently presented overlapped.

\section{COVID-19 pandemic as manufactured risk}

In this section, we show the reasons why COVID-19 epidemic can be considered a manufactured type of threat, in terms proposed by risk society theory. On the one hand, epidemics have plagued humanity throughout history, but on the other hand, the frequency and diffusion seem to be typical of our time (Saker et al. 2004; Wu et al. 2017). Specialists in 
disease ecology indicate that the emergence of new diseases is related to the social and economic model of society, especially with human intervention on the planet and in the environment close to wildlife (Smith et al. 2019). For example, deforestation beyond of devastate the forests and natural resources, also contributes significantly to the emergence of epidemics (Walsh et al. 1993). Human contact with wild fauna, whether through hunting, trade or loss of habitat, is identified as the main cause of the spread of pathogens that cause new diseases, which were previously restricted to wildlife.

The current coronavirus pandemic seems to be, therefore, another example of the reality of a society that lives constantly under a myriad of risks, which are not considered the result of odds or treated solely as natural phenomena. The COVID-19 seems the result of the relationships between the process of industrialization, capital and social interactions. Unknown and unintended threats become a dominant force in society.

In his first book (1992), Beck analyzes the social architecture and the political dimension of potential threats in civilization based on some theses. These theses may be used for analysing COVID-19 pandemic. Either that or any other civilization risk of such dimensions could, at first, be characterized as a self-threat, especially when confronted with these theses proposed by the sociologist:

"(1) Risks produced by the very development of society induce systematic and often irreversible harm, generally remain invisible, are based on causal interpretations, and thus initially only exist in terms of the (scientific or anti-scientific) knowledge about them. They can thus be changed, magnified, dramatized or minimized within knowledge, and to that extent they are particularity open to social definition and construction." (Beck 1992, p. 22-23)

When decision makers deny or minimize the effects of COVID-19, they take an unscientific stance. However, as the pandemic is understood as an invisible and unknown risk, this position gains support from society in the social and political context, as well as allowing different interpretations. Furthermore, the attempt to blame a country for the pandemic ignores the fact that economic globalization presupposes the sharing of responsibilities, since the map of the consumption chain shows, for example, that products sold in North America are manufactured in Asia with inputs brought from Africa.

"(2) Some people are more affected than others by the distribution and growth of risks, that is, social risk position spring up. In some of their dimensions these follow the inequalities of class and strata position, but they bring a fundamentally different distributional logic into play. Risks of modernization sooner or later also strike those who produce or profit from them. They contain a boomerang effect, which breaks up the pattern of class and national society. Ecological disaster and atomic fallout ignore the borders of nations. Even the rich and powerful are not safe from them." (Beck 1992, p. 23)

The social risk position is evident when faced with the consequences of the spread of COVID-19 pandemic in different strata of society. Although rich and developed nations, such as the United Kingdom, France, Italy, Spain and the USA, are mourning the deaths of 
thousands of their citizens, they were able to respond faster to material demands and support to health systems (ECDC 2020). However, populations that are economically and socially deprived suffer the effects of the epidemic much more intensely. In South America, for example, Ecuador's health care and funeral services are collapsing and bodies have been abandoned on the streets (Gallón 2020). Brazil is in first place in the ranking of the pandemic in South America, with more than 28 thousand cases of registered cases (Cazarré 2020) and has difficulties to build new hospitals and to buy equipment and supplies necessary to fight the disease. For example, information about the disease in these populations is inaccurate, the number of contamination can be significantly higher due to underreporting. Some cases are even more worrying, such as that of people living in slum communities, where there is a large concentration of people per square meter, lack of clean water and poor sanitation, which makes it difficult to adopt protective measures against the new coronavirus.

These differences in the position of social risk are substantial, as they imply the way that countries will react against COVID-19, as it is a virus with a high capacity for dissemination. The preliminary estimation of the basic reproduction number of the new coronavirus (SARSCoV-2) is 2.2 (Fauci et al. 2020), that means the average number of new infections that an infectious person can generate in a population that was not previously exposed to the virus. This estimate combined with the lack of access to public health system, basic protection conditions, such as treated water and personal hygiene items, shows an alarming situation that could reach the poorest populations.

"(3) Nevertheless, the diffusion and commercialization of risks do not break with the logic of capitalist development completely, but instead they raise the latter to a new stage. There are always losers but also winners in risk definitions. Modernization risks form the winners' points of view are big business. They are the insatiable demands long sought by economists. Hunger can be sated, needs can be satisfied, but civilization risks are a bottomless barrel of demands, unsatisfiable, infinite, self-producible." (Beck 1992, p. 23)

The current socioeconomic dimensions are based on a complex network composed of workers, companies, suppliers, consumers, technology companies, civil society, financial institutions, policy makers and politicians. However, social isolation measures have led to the blocking, albeit partial, of this network and threaten the current economic system. Economists already assume that the global economic-financial crisis caused by the coronavirus pandemic is the biggest in the last 150 years. So far, the extent of the crisis is uncertain, as, in the opinion of financial market experts, it is difficult to estimate how health systems will face this threat (Rogoff 2020).

Globalization process has generated an increasingly dependent world of economic growth, based mainly on wealth accumulation and, at the same time, it has failed to distribute this wealth. Currently, the world is suffering from the catastrophic effects of the pandemic, caused, in large part, by the lack of investments in disease prevention policies and public health. These effects are also caused by the lack of resources destined to protect the environment, despite the flagrant climate change (Roach 2020). 
As predicted by Beck (1992) periods of crisis caused by civilizational risks, such as the economic catastrophe triggered by COVID-19, can take the capitalist system to a new stage. This crisis could be an opportunity to rethink how the socio-economic system works, but the discourse of decision makers is focusing on the false dilemma between saving lives or saving the economy. If the future remains undefined, at least, there are already suggestions about the new directions for the current economic model. According to the secretary general of the United Nations, António Gutérres, despite the drastic consequences that the pandemic has imposed on society, it also offers a possibility of change (Gutérres 2020).

In this sense, the European Union has also been in favor of a new model of more sustainable post-pandemic capitalism. Among the signatories of a possible "Green Deal" are politicians from different countries, such as the USA, Italy, Germany, Finland, Austria, Luxembourg, among others, as well as legislators, CEOs and entrepreneurs from different sectors.

Seemingly, the spread of COVID-19 has intensified actions against climate change, especially those aimed at reducing carbon emissions. The discourses are based on the current crisis to discuss the urgency of investments aimed at a green economy. The main favorable arguments are the transition to a sustainable economy, the preservation of biodiversity and the sustainability of agribusiness, making changes towards a more resilient society (Baczynska 2020; Vetter 2020).

"(4) One can possess wealth, but one can only be afflicted by risks; they are, so to speak, ascribed by civilization. (...) Knowledge gains a new political significance. Accordingly the political potential of the risk society must be elaborated and analyzed in a sociological theory of the origin and diffusion of knowledge about risks." (Beck 1992, p. 23-24)

In this context, the first actions to fight against the new coronavirus were implemented by the public health system, however with the advance of the disease into a pandemic, help from other institutions was needed, especially to deal with a political bias. Political decisions now affect the public and private sectors, such as the need to nationalize private hospitals in Spain due to the rapid spread of the coronavirus (Güell and Santaeulalia 2020).

Therefore, the risks posed by the pandemic are not only serious problems in public health, but also social, economic and political, such as in the financial market, tourism and unemployment. For example, the decision by countries most affected by the disease to impose restrictive measures of social distancing. Although this guidance comes from specialists in public health, the final decision rests with political leaders, as the measures adopted to combat the pandemic imply other sectors, such as the economic. As a result, decisions at this level are open to different interpretations and ideologies, as in the case of unknown and invisible risks.

In Brazil, for example, due to the controversies related to the false dilemma between saving lives or saving the economy, the President takes a stand against social distancing measures, contrary to the favorable decisions of some Governors and Mayors, including the Ministry of Health (Sandy and Milhorance 2020). This disagreement resulted in the change of command 
of the Ministry of Health, amid the pandemic and the increase in the number of COVID-19 cases in the country (Phillips 2020). The political potential of civilizational risks, as in the case of Brazil, is one of the situations that characterize the risk society. The ability to manage different interpretations of risks requires a reorganization of public authorities and political power, especially in the command hierarchy. "Risk society is a catastrophic society. In it the exceptional condition threatens to become the norm" (Beck 1992, p. 24).

Since the spread of the epidemic, it has become evident that the fight against the disease is not only a public health problem. The effects of COVID-19 are already felt around the world and affect different dimensions of society, such as the labor market, education, social and family relations, political decisions and the environment. An increasing number of infectious diseases arise from this relationship between humans and animals, such as AIDS, SARS and Ebola (Reperant and Osterhaus 2016). Unrestrained consumption and climate change are the main reasons why these new diseases are spreading rapidly around the world. Therefore, it is limiting to think of geographical boundaries with an increasingly interconnected world (Giddens 1990). The classification of COVID-19 as a pandemic is the result of this new global order (Shereen et al. 2020).

What society is currently facing is necessarily the result of a system connected by new technologies, which has been useful for the economy, finance, commerce, communication and travel. However, this same system, essential to the modern model of life, is also responsible for the rapid spread of pathogens capable of causing global catastrophes. There is, therefore, an apparent and inevitable paradox: pathogens (such as Sars-Cov-2) can (and will) emerge as a result of evolution and natural selection, while their transmission will be facilitated through this interconnected system that society became dependent (Mcinnes and Roemer-Mahler 2017).

In 2019, WHO listed, in the report "A World at risk", the main factors that contribute to a higher frequency of outbreaks of infectious diseases: globalized economy, faster travel, migration, climate change and greater urbanization (WHO 2019). Due to these conditions, the WHO has shown that, more and more, high-impact diseases with the potential to spread arise. These diseases are difficult to predict and control and they impact countries at different levels, with a special concern for the most disadvantaged regions and with the greatest inequality. Scientific literature, as in the case of the WHO report (2019), already predicted the possibility of an outbreak of rapid and global dissemination, mainly due to the relationship between humans and wild animals.

This predictability is based both on the current model of society and on the destructive relationship between development and nature, which became real with the COVID-19 pandemic. The crisis caused by this new virus cannot be abstracted from these broader problems. We can use this moment to reflect on the current consumption and development model of society. Manufactured risks, such as global warming, deforestation and pandemics, need to be analyzed broadly and mainly due to their uneven distribution at different socioeconomic levels. The factors that determined the emergence of COVID-19 are related to changes in the environment by human activity. Although the origin of COVID-19 and its path 
of dissemination are not fully understood, we can recognize that the appearance of outbreaks, like the new coronavirus, are risks inherent to the development process of contemporary society.

\section{Perception of Manufactured Risks and How To Deal With Complex Problems}

So far we have presented challenges for science education in developing citizens' autonomous attitudes towards relevant questions in a risk society. Christensen (2009), defends the inclusion of risks subject in school curriculum. He reinforces the relevance of risks themes in school training for citizenship as it can take off from science the full ability to explain, predict and control all kinds of problems. Understanding that science alone cannot offer certainties regarding consume, environment, health and unemployment, allow one to have a proper attitude for contemporary citizenship challenges.

To reach this, school training requires a reconsideration of objects and objectives of teaching and learning. More than just include cross cutting science concepts or situations involving conflicts and games of interest it is necessary to include problems contexts whose allow students to develop competences on perceiving, balancing and making decisions in face of manufactured risks.

In a responsible citizenship, individuals are able to perceive today's risks in an amplified way, as discussed above in Beck and Giddens' terms. That implies at the first moment to analyze knowledge sources that offer ways to access some objective dimension of risks. In this step, science plays a major role: manufactured risks are the ones derived from science and technology taking place in Giddens and Beck reflexive modernity.

Back in 2000's Jenkins had called for inclusion of ability to assess risks as part of a necessary paradigm shift in science education (Jenkins 2000). Assessing risks is a current society demand and students, therefore, should be able to use science as support for that. Jenkins risks, as a place for uncertainties and complexities, are a way for students to bring science into their lives. That would promote a productive engagement and a more effective interaction between students and knowledge as well as between students and society, once they include science uncertainties (Jenkins 2000).

Risk perception has been recurrent in psychologist Paul Slovic's works in the past 25 years. In a seminal work, Slovic (1987) showed a diversity in public perception on risks, including fear, uncertainty, catastrophic potential, control, equity, issues on future generations and so on. To him, less frequent, but with more drastic consequences risks, are perceived as more threatening than risks with less dramatic potential consequences, even being more frequent. Besides, his findings showed legitimate questions carrying values underlying multiple dimensions of risk perception.

However, just like Beck, Slovic (2010) recognizes that despite the reality of danger, there is no such thing as "real risk" or "objective risk". That is, risks estimated by an engineer on 
nuclear accident odds or by a toxicologist on carcinogenic risks of certain chemicals, for example, are modeled risks. Although, for an expert, those models lean on statistics, its structure is, in some level, subjective and carries personal judgments and suppositions. In the same way, lay people form their own intuitive and subjective model, building personal techniques for assessing risks, which are often different from models and techniques scientists use. An example of this subjective aspect is the identity agenda: for people living in areas considered danger, like a neighborhood with contaminated soil or under threat of mudslides, there is always a social bond in the community and emotional and historical factors, related to the place. In cases like those, experience showed that compulsory moving had been traumatic for people, despite personal and collective safety issues (Giulio et al. 2015).

Risk perception is also affected by the amount and the quality of available information, specially when situation is sensible, with direct consequences to individuals under risks (Slovic, Flynn, and Layman 1991; Slovic 2000; Joffe 2003; Bickerstaff et al. 2004; Bursztyn and Eiró 2015). Also Beck (2013) argues that experiences and risk perceptions are not the same for everyone. Similar to Douglas (1966), as using a sociological ground Beck reinforces that experiences are, then, marked by shared cultural aspects. Thus, risk perception is dependent on both the ways people feel they will be affected by threatening events and the ways institutions will inform them about it (Wilkinson 2001).

In the face of emergency situations, as pandemics, people tend to absorb and process information as well as act differently from usual. This means that risk perception varies according to the situation's severity and it depends on the degree of threat. A recognized pandemic, for which there are well defined protocols, will lead to a weaker risk perception for the general public, compared to an unknown epidemic, with no science standard orientation, even if the former could represent higher danger to health (Gentili et al. 2019).

Then, knowing the role of possible factors for risk perception allows the understanding of how individuals act when facing uncertain situations. This is relevant because underlying an act there must be a decision making. Pandemics, as the current COVID-19, are precise examples for understanding how risk perception affects people behavior and attitudes. Besides, the ability of recognizing risks in a broader sense, that is, being conscious about availability or lack of regarding scientific knowledge and including risk impacts in people's lives both at individual and collective levels, assessing information given by public agencies a decisions made by them are determinant factors for success or failure in fighting threatening situations.

Risk perception and its subsequent decision making require more than specific scientific knowledge and an immediate common sense of threats potential impact. Thus, we propose the notion of amplified risk perception in order to embrace risk society challenges. This kind of perception fits in the profile of manufactured risks taking place in a globalized world, interconnected by technologies. That implies to expand foci of analysis in order to develop students' ability in assessing short, mid and long-term risk conditions. In Figure 1 ahead, we present a scheme for amplified consideration of risk perception. It localizes perception, 
according to what dimensions are available and how local or global risks are perceived.

The schema below was developed during many research group sessions about the implications of risk society and people's perceptions of manufactured risk. It shows a gradual scale, defining a risk perception space, which includes three dimensions: access, urgency and range. Access is associated with rational thinking supported by scientific cognition. Urgency defines a hierarchy of risk connected with values and practices in a given culture. Range is connected with the ability to make impact assessments either in a close or far perspective. This dimension is strongly mediated by information. Combined, they indicate a level of risk perception coverage. This three dimensional risk perception space indicates one's (or group's) ability to perceive risks related to a particular situation. Thus there is a sort of a "risk perception vector" (RPV), which indicates locality or globality. The greater is the vector magnitude, the broader is perception. Smaller magnitudes indicates more restrictive risk perception. Thus, this magnitude indicates if risk perception are directed to local/individual or to global/collective realm. The direction RPV has in the risk perception space indicates how diversified is the perception: for example, more committed with rational dimension (projected in the access axis). The scheme can be helpful to identify risk perception features. Manufactured risks, for example, draw on the external region of the risk perception space. Then, a RPV vector projected in a plane or in a single axis indicates a monovalent perception of risk. In any case, the scheme may help to establish the state of individual/group consideration in face of a threat situation.

have global and collective consequences and its perception

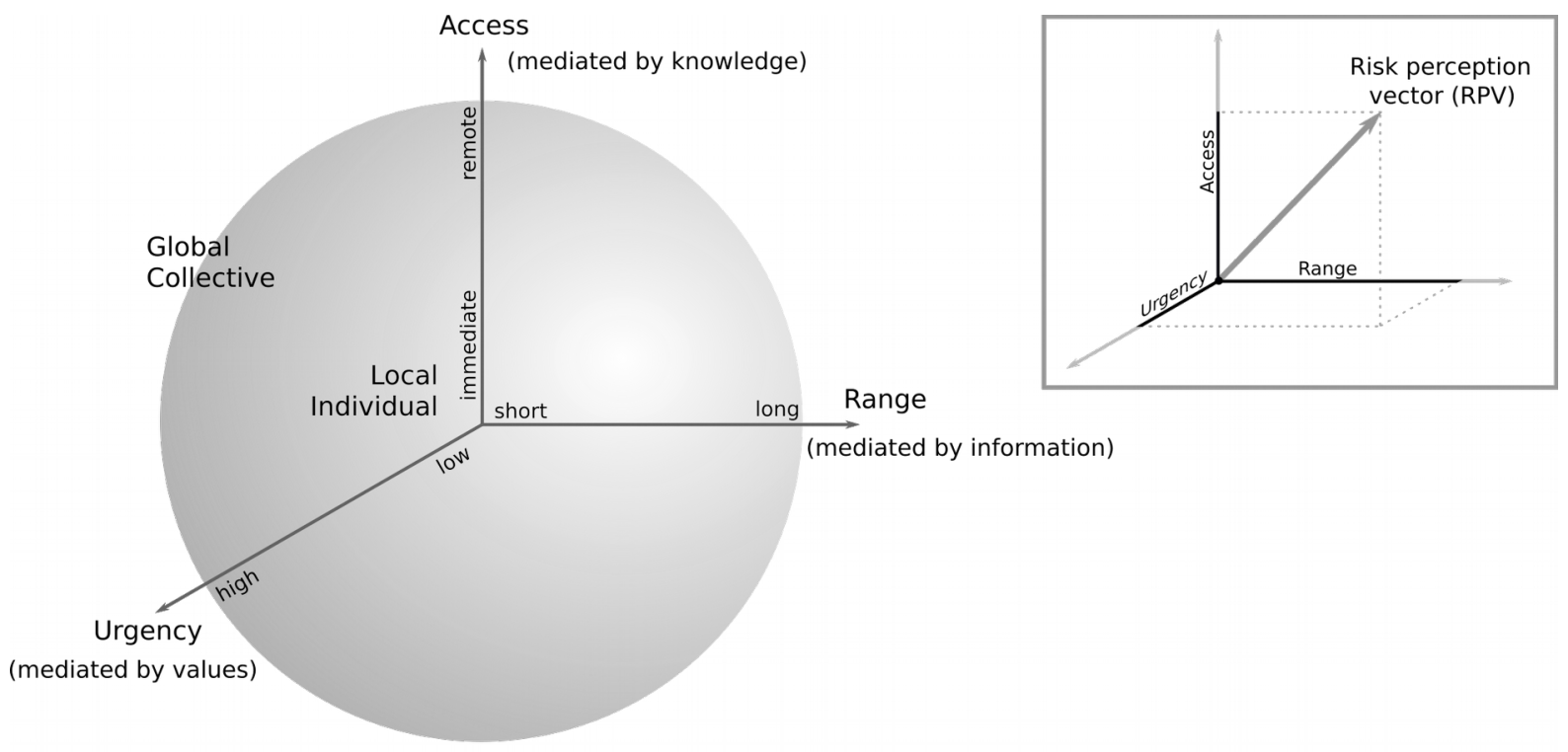

Figure 1: Scheme of a three dimensional risk perception space. In highlight, perception location in risk perception space.

As an exercise, we take a current COVID-19 pandemics and propose what may be an 
amplified risk perception about it.

By the beginning of December, 2019, first cases of an yet unknown disease was registered in Wuhan province, China. This is the origin of COVID-19. In three months, the disease has spread in more than 150 countries. By March 11 $1^{\text {th }}, 2020$, WHO declared COVID-19 as a pandemic, showing its global reach. The pandemic changed daily routines, imposing social distance, closing schools and stores. This scenario guides people's perception, considering both global and local impacts and requiring a constant assessment of individual and collective risks.

Range (mediated by information): A short range perception will consider that actions to prevent COVID-19 are excessive or unnecessary if their relatives and friends are not sick or if the number of people infected in their city is low. There would be no search for new sources of information and decisions will continue to be made based on usual and local information. Competence for identifying fake news will be reduced as sources of information are few and many times unreliable. A long range perception will compare common sense information with data from multiple and reliable sources to build a wider view of the pandemic. A wider perception will identify information which are minimally agreed among sources and others which are still uncertain and require prudence. In both cases the decision maker will act in the protection of itself and others in agreement with the global risk perception and collective sense.

Access (mediated by knowledge): An immediate access will perceive SARS-CoV-2 as a comun virus like influenza ones, with similar effects on the human body, such as, cough, headeak, fever. Drugs like analgesics and anti-thermics may restore your health in a week. As usual, soon or later a vaccine will be produced and save people from the disgust of being ill. There would be no action required from decision makers because this virus offers no threat to people in general. A remote access will perceive that COVID-19 proliferates more than the influenza virus as researchers strive to understand the virus mechanisms in order to produce a vaccine. It is because, as any virus, the degree of mutation may challenge the search for a vaccine. The medium time to have a vaccine is around 18 months and certainly it was not a solution for the present time. As it is a new disease, there are remaining questions such as questions on a second infection or questions on higher temperature transmission rates. This is a condition that leaves open the interpretation of risk perception on COVID-19, allowing other institutional voices, besides science. This is the context in which decision makers opt for acting, in practice or in discourse, differently from WHO orientations or scientific knowledge produced so far.

Urgency (mediated by values): a low urgency will consider that its personal values can be the main, if not, the only reason that matters. For instance, even in the face of the exponential rate of death caused by COVID-19 in many places, there are still those who defend the open of stores, malls, and general trades on behalf of the economy. Their personal values (such as financial interests, ideological, political ones, and so on) are more important than the risks. A high urgency regarding COVID-19 will be expressed through the recognition that, in times like these, individual values (whatever they are) can't be overlapped with public health. It can 
be portrayed through decisions made by politician actors, in spite of their political or ideological disagreements. In some countries, different State and Municipal chiefs have worked together to elaborate public policies in order to mitigate the COVID-19 damages. Thus, the mobilization of people with completely divergents views and ideologies that join to fight against a common enemy, such as COVID-19 pandemy, is a concrete example of a high perception of urgency.

The analysis made with the risk perception scheme may establish the amplitude of risk perception and orient an action plan in science education or even in a campaign for public orientation. The axes in risk perception space are an abstraction for measuring risk perception features, tracing risk perception coverage. It aims to give some qualitative metrics on objective and subjective aspects of risk perception. In order to exert citizenship in respect to reflexive modernity, external regions in risk perception space are desirable and thus science education objectives must include amplification of perception of manufactured risk.

\section{Wicked problems}

We must stress that, similar to other socio-scientific issues, manufactured risks need to be explicitly discussed and socially rationalized, once it embraces epistemological, psychological, cultural and pedagogical aspects. Thus the most fruitful place for doing so is the scholar environment. A place where students can develop their democratic citizenship, becoming able to participate in controversies recognizing risks generated by contemporary techno-science and making well informed decisions (Levinson 2010).

Comprehending scientific concepts is, naturally, indispensable. But not only. Social and cultural perspectives, as affecting risk perception, must be taken in the account, since the goal is to develop active participation of individuals in society. Contextualization of complex problems and science limitations can promote students' interest in science as recognizing its epistemology and its potential as a source of information for solving socio-scientific issues (Levinson et al. 2011). Going beyond merely including the nature of science, a particular kind of problems must be considered, in order to include the features of manufactured risks.

Problem solving has always been the basis for science education and works as a teaching and learning engine, as learning becomes more efficient by working on solving real world problematic contexts (Dewey 1916; Wong and Pugh 2001). The importance of problem solving is still in place for science education from a risk society perspective. Problem solving also configures one of the basis for developing contemporary citizens in risk society, as they help to develop essential competences in using knowledge.

However, risk problems we are discussing here are different from traditional or "exemplars" (Kuhn 1970, postscript). Kuhn's exemplars are problems produced for materializing some pragmatic aspect of a theory. They have some standard solution, agreed by scientific communities. In this sense, during the training of a scientist it is expected solvable problems to be discussed, once they have been previously validated by the scientific community. Thus, exemplars work as a way for retaining "normal science" itself. Normal science exemplar 
situations are already known problems, allowing certain solutions and, therefore, for the risk perspective we are presenting, they fail. Exemplars can be thought of as false problems, as in Pólya's (1945) original sense, once they mostly assume the existence of consensual solutions a priori and the issue to be solved is how to make students to access those solutions. When bringing this reasoning to science education in basic school, students are exposed to "shared examples" of problems contexts. Learning, then, leans on previous conceptual baggage, defined by science tradition, assuming that students would reach similar solutions for similar problems. That process also assumes that students' rationality matrix can be transposed from one to another context (Abrantes 1998).

Manufactured risks situations, though, are marked by the lack of analogies or exemplars from which a particular framework can be compared and/or transposed. In manufactured risk problems there is no search for all possible variables, nor for a precise or correct functioning of the system. However legitimate good practices may be in a known situation or however analytical approaches may be in a knowable situation, per-existent rationality matrices fail in dealing with risk situations. These kinds of problems are better defined as complex problems or wicked problems (Van Beurden and Kia 2018). In recent editorial, on a special number about health issues, Eric Van Beurden and Annie Kia wrote:

"What do complex issues such as inequality, climate disruption, food, insecurity and obesity challenge us to learn? These are Wicked problems that require action at every scale. With multiple, interaction causes, solutions lie well beyond the traditional domain of any jurisdiction or organizational entity and beyond business-as-usual." (Van Beurden and Kia 2018, p. 83)

Wicked problems seem to challenge the conception of regular problems. They take place in an opposite spectrum compared to Kuhn's exemplars. That is because wicked problems do not only lack solutions a priori but also because any acceptable solution given in a particular time and space may no longer be acceptable in further moments.

Kurtz and Snowden (2003), working on ways to prepare managers for decision making under crisis situations, in which contexts are highly uncertain, developed a way to typify problems classes for defining acting strategies. They propose the Cynefin model (fig. 2) for structuring decision making on four classes of problems: i) known problems, in which causal relations are visible and predictable, there are no uncertainties involved and are legitimated by good practices, once problem reproducibility is characteristics; the ii) knowable problems, in which cause-effect relations are separated over time and solutions are reach by an analytical attitude for planning scenarios and a systemic view is necessary for for decision making; the iii) complex problems, in which cause-effects can only be accessed in hindsight, solutions aim management of emerging patterns and there is a need for adaptations to situation; and last the iv) chaotic problems, in which cause-effect relations can not be perceived, nor even in retrospect, thus, decisions aim only stability.

The Cynefin model (Figure 2), here used for understanding manufactured risks as complex scenarios, having emergent causality with no a priori. Named after a welsh word (Snowden 
2002), the term can be understood as situations in which there is a failure of justice. In complex and uncertain situations, marked by non-linearity, robustness and feedback, there are no adequate previous models. To Kurtz and Snowden (2003), Cynefin perspective is fitted to understanding real scenarios as being:

"the place of our multiple affiliations, the sense that we all, individually and collectively, have many roots, cultural, religious, geographic, tribal, and so forth. We can never be fully aware of the nature of those affiliations, but they profoundly influence what we are. [...] all human interactions are strongly influenced and frequently determined by the patterns of our multiple experiences, both through the direct influence of personal experience and through collective experience expressed as stories." (Kurtz and Snowden 2003, p. 467)

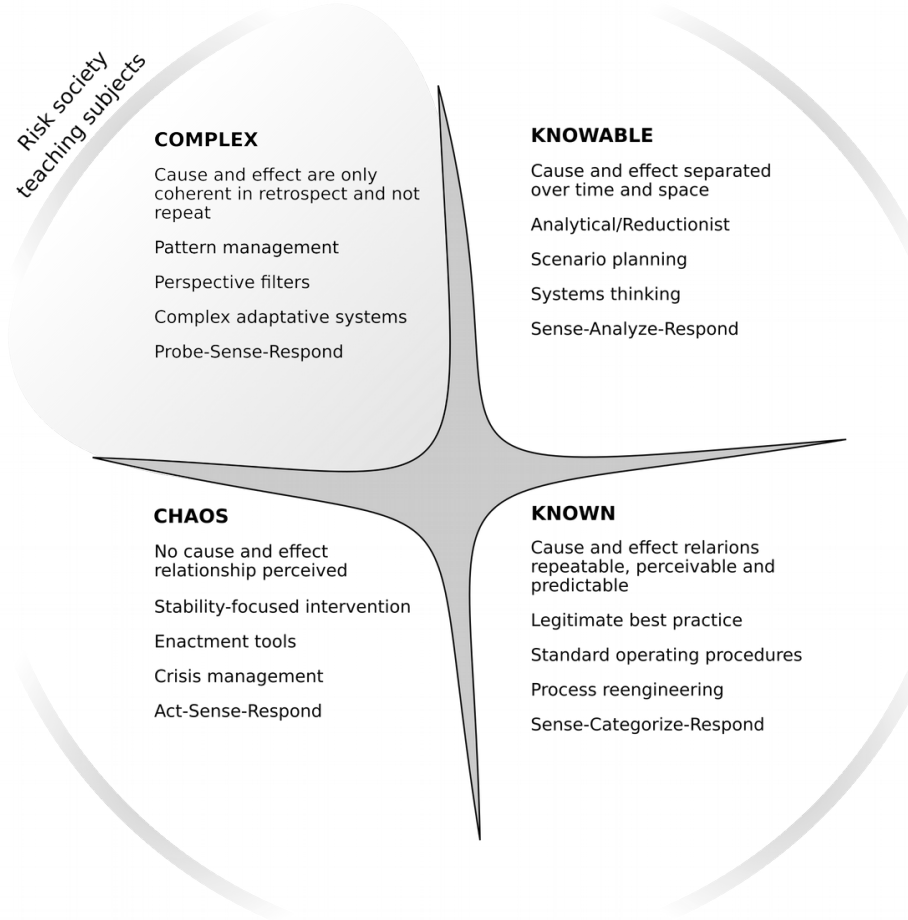

Figure 2: Cynefin framework for decision making, by type, highlighting the kind of problems and teaching content to be taught in science classes. Adapted from Kurtz and Snowden (2003).

In an ordered domain, there is a focus on efficiency. Organized systems converge to reductionist approaches, prevailing summative features over constitutive ones, i.e. the whole can be characterized as the sum of its parts. However, risk perception occurs in non-ordered situations, in which the whole can note be characterized as the sum of its parts. Thus, complex scenarios can not take advantage of causal relations taken a priori.

In the Cynefin model, Kuhn's exemplar problems seem to fit in the "known" quadrant, once they assume a clear and directed causal relation. Possible problems formulated inside a paradigm, could fit "knowable" quadrant, generating new knowledge inside a specialty field of a focused paradigm.

The multitude of influences described by Kurtz and Snowden opposes reduction or 
disciplinarization, which by its turn would work only in ordered situations, such as exemplars problems. This in a sense that they imply non-linear causal relations, they do not involve few actors, they are not free from dilemmas, they have uncertain unfolding in its temporal and spatial reaching, and they take temporary solutions. This is the profile of contexts in which manufactured risks are incorporated as a teaching and learning subject.

With that said, it is feasible to assume that manufactured risks take place as a kind of socioscientific issues, in intricacy situations, being inherently complex. They cannot be guided by any a priory elements and they fail in their predictive power, something that characterizes traditional science teaching. Thus risk perception must end up in attitudes and action plans dependent, first, on what emerges from human action in the world. They are non-ordered realities in which any action feedbacks in the system. This means that any intervention is also a moment of a diagnosis and at the same time, any diagnostics in a moment for intervening. Teaching content in risk society are those in which human acts change the world's nature and at the same time, the world changes the nature of human acts.

The Cynefin model is an efficient tool for classifying and comprehending complex problems as the manufactured risk ones, derived from science and technology development. Decision making in face of complex problems may require concessions: in a complex system, sometimes it is necessary to allow that part of the system to work in a sub-optimal way in order for the whole system to work in its optimal way.

COVID-19 pandemics exemplifies some aspects of complex problems from the Cynefin model. Health systems collapse, macroeconomic global impacts and transnationality of the virus spread mutually influence each other and feedback the situation. Thus, indicated actions by official health institutions, such as social distance, are ways for managing emergent patterns in order to adapt to the constant evolution, instant by instant, looking at pandemic data.

The current pandemics have consequences we will only know more widely in the near future and which fully understanding will be only possible by looking back, shows that there would be no a priori for an exemplar problem context to be taught. This is inherent to manufactured risk situations. That indicates that teachable manufactured risks situations problems are (i) necessarily open problems, but not only; (ii) they require crosscutting concepts, but a single conceptual frameworks is not enough to make decisions; (iii) they depend on amplified perception and assessment of multiple causal entities in interaction; and because of that they are (iv) wicked problems, in which science teaching aims to develop decision making competences using coherent and acceptable attitudes in opposition to correct answers typical from traditional science problems.

\section{Final Considerations and Conclusions}

The underlying (and future defining) questions of global order, guiding this work was: why 
should we invest in people's beliefs? The answer for this question may drive people's either individual or collective attitude. The ability to assess enrolled manufactured risks and the competences for dealing with them are crucial for overcoming current pandemic and other future crises. Current situation demands individuals to deal with a threat whose effects are close but whose origin is distant and unfolds in a context of complex relations, including local and global factors. That raises the reflection on what would be the proper scientific and technological science education for today and for the future.

From our reflections on what would be relevant to deal with civilization, thus intra-social, thus manufactured risks, we wrapped up two main considerations for science education. First, it is needed to invest in diversity of the kind of problems brought to school science curricula. Particularly, the absence of wicked problems, among the mainstream science problems, gives students a false impression that science problems are always the ones with clear causal relations between context and solution. As if all problems would be, after all, exemplars, in Kuhn's sense. Brousseau shows evidence of how students are able to solve chaotic or absurd problems brought to scholar contexts using naïve strategies (Brousseau, 1987). Although those problems had been studied in primary education, there is no reason to think that the same could not be done in secondary or higher education.

Knowing how to classify problems in Cynefin framework is another valuable competence, once its consequence is to diversify problem solving approach according to resources availability and to problem features. Thus, aiming problem contexts from manufactured risks, such as climate, environment, health, moral dilemma, etc., can promote a set of complex (wicked) problems. Then, developing particular abilities for dealing properly with this kind of problem is developing students citizenship itself. Mostly, difficulties in fighting manufactured risk comes from simplistic or a reductionist approach, associated with problems with an immediate solution (known problems) or the ones whose solutions are in a near horizon (knowable problems). In contrast, widening conscious risks considerations take problems contexts beyond, fitting into complexity.

Schenk and colleagues (2019) forward a similar suggestion as they develop a model for relating subjective and objective features of risk. They propose a multidimensional conception of risks, recognizing close relations between risk and decision making. Their model includes "activity" as a basis for risk problems, being characterized by human actions that drive to risks but also attitudes for inhibiting it; "values" and "knowledge" figuring the same epistemic niche, interacting and giving subjective features to risk, the former, and objective features, the latter. Despite parity between knowledge and values, they can weigh differently in risk assessment. Also "uncertainty", "probability", "severity" and "consequence".

Another aspect is the amplification of risk perception, considering both local/individual and global/ collective spheres. The contemporary role of science education in developing citizenship cannot be coupled with a continuous progressive wellness. Scientific and technological knowledge were fundamental for solidifying people's ontological security. Apparently, that faded away some moment in post-war. Learning to live in a world where the 
future is opaque and in which decisions must be made under uncertainties is the new educational edge to be pursued. It is impossible to avoid making decisions in conflicting scenarios in which knowledge and information brought from science and technology are subjected and interchangeable to contradictory views. As Giddens (1990) stated:

"To recognize the existence of a risk or set of risks is to accept not just the possibility that things might go wrong, but that this possibility cannot be eliminated. The phenomenology of such a situation is part of the cultural experience of modernity in general." (Giddens 1990, p. 111)

We can say that taking an amplified perception on risks is being able to project not only certainties of present but specially feasible futures, despite its uncertainties. In this perspective, science plays a new role, promoting awareness and consciousness on risks. Not as a place for certainties but as a source for legitimation of decisions that defined society choices. More than ever, science education must aim to prepare individuals to establish a more engaged and dialogical relation between science, technology and its unfolding.

Modern society, in general, still lacks ways to deal with manufactured risks. Nowadays, institutions are not yet able to monitor scientific and technological changes and its influences in people's way of life. Science education shall fulfill this shortfall at an institutional level, ergo supporting people's ability to deal with manufactured risks that rises from the sciencetechnology-society amalgam.

\section{Acknowledgments}

The authors would like to thank the members from the NUPIC research group from University of São Paulo.

Funding Information This study was funded in part by National Council of Research (CNPq) and the 'Coordenação de Aperfeiçoamento de Pessoal de Nível Superior-Brasil' (CAPES)-Finance Code 001 and by Institute of Advanced Studies from University of São Paulo.

\section{Compliance with Ethical Standards}

Conflict of Interest The authors report no conflict of interest in the research from which this paper has been derived

\section{References}

Abrantes, P. (1998). Kuhn e a noção de exemplar. Principia: an international journal of epistemology, 2(1), 61-102. 
Aikenhead, G. S. (2006). Science Education for Everyday Life: Evidence-Based Practice. (R. A. Duschl, Ed.). New York: Teachers College Press.

Alves, L. G. A., Mangioni, G., Cingolani, I., Rodrigues, F. A., Panzarasa, P., \& Moreno, Y. (2019). The nested structural organization of the worldwide trade multi-layer network. Scientific Reports, 9(1), 1-14. doi:10.1038/s41598-019-39340-w

Australian Curriculum, Assessment and Reporting Authority. (2014). The Australian curriculum. https://www.australiancurriculum.edu.au/Home. Accessed 15 September 2019.

Baczynska, G. (2020). The EU looks towards green coronavirus recovery. World Economic Forum. https://www.weforum.org/agenda/2020/04/european-politicians-ceos-lawmakersurge-green-coronavirus-recovery. Accessed 17 April 2020.

Barry, C., \& Ferracioli, L. (2016). Can Withdrawing Citizenship Be Justified? Political Studies, 64(4), 1055-1070. doi:10.1177/0032321715606569

BBC. (2020). Coronavirus: US accused of 'piracy' over mask 'confiscation.' BBC News World. https://www.bbc.com/news/world-52161995. Accessed 6 April 2020.

Beck, U. (1992). Risk society : towards a new modernity. Sage Publications. https://uk.sagepub.com/en-gb/eur/risk-society/book203184. Accessed 16 February 2019.

Beck, U. (1995). Ecological Politics in an Age of Risk. Cambridge: Blackwell Publishers. Beck, U. (1999). World Risk Society. Cambridge, MA: Polity Press.

Beck, U., Blok, A., Tyfield, D., \& Zhang, J. Y. (2013). Cosmopolitan communities of climate risk: Conceptual and empirical suggestions for a new research agenda. Global Networks, 13(1), 1-21. doi:10.1111/glob.12001

Beck, U., Giddens, A., \& Lash, S. (1994). Reflexive Modernization Politics, Tradition and Aesthetics in the Modern Social Order. Stanford: Stanford University Press.

Bickerstaff, K., Simmons, P., \& Pidgeon, N. (2004). Public perceptions of risk, science and governance: main findings of a qualitative study of six risk cases. Norwich, UK.

Brousseau, G. (1986). Fondements et méthodes de la didactique des mathématiques. Recherche en didactique des mathématiques, 7(2), 33-115.

Buckee, C. O., Balsari, S., Chan, J., Crosas, M., Dominici, F., Gasser, U., et al. (2020). Aggregated mobility data could help fight COVID-19. Science, 368(6487), 145 LP - 146. doi:10.1126/science.abb8021

Bursztyn, M., \& Eiró, F. (2015). Mudanças climáticas e distribuição social da percepção de risco no Brasil. Sociedade e Estado, 30(2), 471-493. https://doi.org/10.1590/S0102- 
699220150002000010

Cazarré, M. (2020). América do Sul registra mais de 58 mil casos de covid-19. EBC Agência Brasil. Montevidéu. https://agenciabrasil.ebc.com.br/internacional/noticia/202004/america-do-sul-registra-mais-de-58-mil-casos-de-covid-19. Accessed 15 April 2020.

Christensen, C. (2009). Risk and school science education. Studies in Science Education, 45(2), 205-223. doi:10.1080/03057260903142293

Deloirs, J., Muffi, I. A., Amagi, I., Carneiro, R., \& Chung, F. (2010). Educação: um tesouro a descobrir, relatório para a UNESCO da Comissão Internacional sobre Educação para o Século XXI. Brasília, DF.

Dewey, J. (1916). Democracy and education: An introduction to the philosophy of education. New York: MacMillan.

Giulio, G. M., Vasconcellos, M. da P., Günther, W. M. R., Ribeiro, H., \& de Assunção, J. V. (2015). Percepção de risco: Um campo de interesse para a interface ambiente, saúde e sustentabilidade. Saúde e Sociedade, 24(4), 1217-1231. doi:10.1590/S0104-12902015136010

Douglas, M. (1966). Purity and danger: an analysis of concepts of pollution and taboo. London, UK: Routledge and Kegan Paul.

Douglas, M. (1994). Risk and Blame: Essays in Cultural Theory. London: Routledge.

Douglas, M., \& Aaron Wildavsky. (1983). Risk and Culture An Essay on the Selection of Technological and Environmental Dangers. University of California Press.

ECDC. (2020). Situation update worldwide, as of 5 April 2020. European Centre for Disease Prevention and Control. https://www.ecdc.europa.eu/en/geographical-distribution-2019-ncovcases. Accessed 5 April 2020.

Embury-Dennis, T. (2020). Coronavirus: Turkey accused by officials of seizing hundreds of ventilators paid for by Spain. The Independent.

https://www.independent.co.uk/news/world/europe/coronavirus-turkey-spain-ventilatorsmedical-equipment-seized-a9447216.html. Accessed 25 April 2020.

England (2014). The National Curriculum in England. Department For Education. https://assets.publishing.service.gov.uk/government. Accessed 15 April 2020.

Fauci, A. S., Lane, H. C., \& Redfield, R. R. (2020). Covid-19 - Navigating the Uncharted. The New England journal of medicine, (Editorial). doi:10.1056/NEJMe2002387

Gallón, N. (2020). Bodies are being left in the streets in an overwhelmed Ecuadorian city. CNN Americas. https://edition.cnn.com/2020/04/03/americas/guayaquil-ecuador- 
overwhelmed-coronavirus-intl/index.html. Accessed 15 April 2020.

Gentili, D., Bardin, A., Ros, E., Piovesan, C., Ramigni, M., Dalmanzio, M., et al. (2020). Impact of Communication Measures Implemented During a School Tuberculosis Outbreak on Risk Perception among Parents and School Staff, Italy, 2019. International journal of environmental research and public health, 17(3), 911. doi:10.3390/ijerph17030911

Giddens, A. (1990). The consequences of modernity. Stanford, CA: Stanford University Press.

Giddens, A. (1991) Modernity and Self-Identity: Self and Society in the Late Modern Age. Cambridge: Polity Press.

Giddens, A. (1999). Risk and Responsability. The Modern Law Review, 62(1), 1-10. doi:10.1111/j.1468-2230.1937.tb00023.x

Güell, O., \& Santaeulalia, I. (2020). El Gobierno pone los hospitales privados a las órdenes de las comunidades. El país. Madrid. https://elpais.com/espana/2020-03-15/el-gobierno-ponelos-hospitales-privados-a-las-ordenes-de-las-comunidades.html. Accessed 23 March 2020.

Gutérres, A. (2020). The recovery from the COVID-19 crisis must lead to a different economy. United Nations. https://www.un.org/en/un-coronavirus-communicationsteam/launch-report-socio-economic-impacts-covid-19. Accessed 17 April 2020.

Hall, S. (1992) The Question of Cultural Identity. In: S. Hall; D. Held; T. Mcgrew (Eds.) Modernity and its Futures (pp. 273-316). Cambridge, UK: Polity Press/Open University Press.

Hansen, J., \& Hammann, M. (2017). Risk in Science Instruction: The Realist and Constructivist Paradigms of Risk. Science and Education, 26(7-9), 749-775. doi:10.1007/s11191-017-9923-1

Hodson, D. (1992). In search of a meaningful relationship: an exploration of some issues relating to integration in science and science education. International Journal of Science Education, 14(5), 541-562. doi:10.1080/0950069920140506

Hodson, D. (2011). Looking to the future : building a curriculum for social activism. Rotterdam. The Netherlands: Sense Publishers.

House of Lords (2000). Science and Technology - Third Report, Science and Technology Committee Publications, London: House of Lords.

Hsu, E. L. (2011). Social theory and globalization. In Anthony Elliot (Ed.), Routledge Companion to Social Theory (pp. 203-218). London, UK: Routledge. 
Jenkins, E. (2000). "Science for all': Time for a paradigm shift? In R. Millar \& J. F. Osborne (Eds.), Improving science education: The contribution of research (pp. 207-226).

Buckingham, UK: Open University Press.

Joffe, H. (2003). Risk: From perception to social representation. British Journal of Social Psychology, 42(1), 55-73. https://doi.org/10.1348/014466603763276126

Kolstø, S. D. (2001). Scientific literacy for citizenship: Tools for dealing with the science dimension of controversial socioscientific issues. Science Education, 85(3), 291-310. https://doi.org/10.1002/sce.1011

Kraemer, M. U. G., Yang, C.-H., Gutierrez, B., Wu, C.-H., Klein, B., Pigott, D. M., et al. (2020). The effect of human mobility and control measures on the COVID-19 epidemic in China. Science, eabb4218. doi:10.1126/science.abb4218

Kreuger, S. B., \& Ramos, P. (2017). Concepções De Cidadania Na Educação Em Ciências: O Que Dizem Os Projetos Político-Pedagógicos E Os Professores De Escolas Municipais De Petrópolis - Rj. Ensaio Pesquisa em Educação em Ciências (Belo Horizonte), 19(0), 1-23. doi:10.1590/1983-21172017190132

Kuhn, T. (1970). The structure of scientific revolutions (2nd ed.). London, UK: University of Chicago Press.

Kurtz, C. F., \& Snowden, D. J. (2003). The new dynamics of strategy: Sense-making in a complex and complicated world. IBM Systems Journal, 42(3), 462-483. doi:10.1147/sj.423.0462

Levinson, R. (2010). Science education and democratic participation: An uneasy congruence? Studies in Science Education, 46(1), 69-119. doi:10.1080/03057260903562433

Levinson, R., Kent, P., Pratt, D., Kapadia, R., \& Yogui, C. (2011). Developing a pedagogy of risk in socio-scientific issues. Journal of Biological Education, 45(3), 136-142. doi:10.1080/00219266.2011.576260

Levinson, R., Kent, P., Pratt, D., Kapadia, R., \& Yogui, C. (2012). Risk-based decision making in a scientific issue: A study of teachers discussing a dilemma through a microworld. Science Education, 96(2), 212-233. doi:10.1002/sce.21003

Mcinnes, C., \& Roemer-Mahler, A. (2017). From security to risk: Reframing global health threats. International Affairs, 93(6), 1313-1337. doi:10.1093/ia/iix187

Mendelson, D. (2010). Central Terms and Thinkers. In A. Elliot (Ed.), The Routledge Companion to Social Theory. London, UK: Routledge.

Millar, R. (2006). Twenty First Century Science: Insights from the Design and 
Implementation of a Scientific Literacy Approach in School Science. International Journal of Science Education, 28(13), 1499-1521. doi:10.1080/09500690600718344

Mythen, G. (2018). The Critical Theory of World Risk Society: A Retrospective Analysis. Risk Analysis, 18(2).

Osborne, J. F., \& Millar, R. (1998). Beyond 2000: Science Education for the Future Paperback. King's College London,Department of Education and Professional Studies.

Paek, H.-J., \& Hove, T. (2017). Risk Perceptions and Risk Characteristics. Oxford Research Encyclopedias.

Phillips, D. (2020). Bolsonaro ignored by state governors amid anger at handling of Covid-19 crisis. The Guardian. https://www.theguardian.com/world/2020/apr/01/brazil-bolsonaroignored-by-state-governors-amid-anger-at-handling-of-covid-19-crisis. Accessed 18 April 2020 .

Ratcliffe, M., \& Grace, M. (2003). Science education for citizenship: teaching socioscientific issues. Milton Keynes: Open University Press.

Reperant, L. A., \& Osterhaus, A. D. M. E. (2017). AIDS, Avian flu, SARS, MERS, Ebola, Zika... what next? Vaccine, 35(35, Part A), 4470-4474.

https://doi.org/https://doi.org/10.1016/j.vaccine.2017.04.082

Rittel, H. W. J., \& Webber, M. M. (1973). Dilemmas in a general theory of planning. Policy Sciences, 4(2), 155-169. doi:10.1007/BF01405730

Roach, S. S. (2020). Why decisive health action matters more than financial decisions in the COVID-19 crisis. World Economic Forum.

https://www.weforum.org/agenda/2020/03/covid19-economic-crisis/. Accessed 17 April 2020.

Rogoff, K. (2020). The 2008 financial crisis will be seen as a dry run for Covid-19 cataclysm. The Guardian. https://www.theguardian.com/business/2020/apr/08/the-2008-financial-crisiswill-be-seen-as-a-dry-run-for-covid-19-cataclysm. Accessed 17 April 2020.

Saker, L., Lee, K., Cannito, B., Gilmore, A., \& Diarmid Campbell-Lendrum. (2018). Globalization and infectious diseases. Special Topics in Social, Economic and Behavioural (SEB) Research - WHO. Geneva. doi:10.1016/B978-1-78548-277-9.50008-5

Sandy, M., \& Milhorance, F. (2020). Brazil's President Still Insists the Coronavirus Is Overblown. These Governors Are Fighting Back. Time. https://time.com/5816243/brazil-jairbolsonaro-coronavirus-governors/

Schenk, L., Hamza, K. M., Enghag, M., Lundegård, I., Arvanitis, L., Haglund, K., \& Wojcik, 
A. (2019). Teaching and discussing about risk: seven elements of potential significance for science education. International Journal of Science Education, 41(9), 1271-1286. doi:10.1080/09500693.2019.1606961

SEPUP. (2018). Decision Making: Probability and Risk Assessment. Science Education for Public Understanding Program. https://sepuplhs.org/middle/modules/decision/index.html. Accessed 17 April 2020

Shereen, M. A., Khan, S., Kazmi, A., Bashir, N., \& Siddique, R. (2020). COVID-19 infection: Origin, transmission, and characteristics of human coronaviruses. Journal of Advanced Research, 24, 91-98. https://doi.org/https://doi.org/10.1016/j.jare.2020.03.005

Slovic, P. (1987). Perception of Risk. Science, 236(4799), 280-285.

Slovic, P. (2000). Risk, society, and policy series. The perception of risk. Earthscan Publications.

Slovic, P. (2010). The Psychology of risk. Saúde e Sociedade, 19(4), 731-747. doi:10.1590/S0104-12902010000400002

Slovic, P., Flynn, J. H., \& Layman, M. (1991). Perceived Risk, Trust, and the Politics of Nuclear Waste. Science, 254(5038), 1603 LP - 1607.

https://doi.org/10.1126/science.254.5038.1603

Smith, K. M., Machalaba, C. C., Seifman, R., Feferholtz, Y., \& Karesh, W. B. (2019). Infectious disease and economics: The case for considering multi-sectoral impacts. One Health, 7(June 2018), 100080. https://doi.org/10.1016/j.onehlt.2018.100080

Snowden, D. (2003). Complex acts of knowing: Paradox and descriptive self-awareness. Journal of Knowledge Management, 6(2), 100-111. doi:10.1108/13673270210424639

Sørensen, M. P. (2018). Ulrich Beck: exploring and contesting risk. Journal of Risk Research, 21(1), 6-16. doi:10.1080/13669877.2017.1359204

Van Beurden, E., \& Kia, A. (2011). Editorial - Wicked problems and Health Promotion: reflections on learning. Health Promotion Journal of Australia, 22(2), 83-84. doi: $10.1071 /$ he11083

Vesterinen, V. M., Tolppanen, S., \& Aksela, M. (2016). Toward citizenship science education: what students do to make the world a better place? International Journal of Science Education, 38(1), 30-50. doi:10.1080/09500693.2015.1125035

Vetter, D. (2020). Use Lessons Of COVID-19 To Build A Green Recovery, Say EU Ministers. Forbes. https://www.forbes.com/sites/davidrvetter/2020/04/13/use-lessons-of-covid-19-tobuild-a-green-recovery-say-eu-ministers/\#6fe1617b4335. Accessed 17 April 2020.

Walsh, J. F., Molyneux, D. H., \& Birley, M. H. (1993). Deforestation: effects on vector-borne 
disease. Parasitology, 106(S1), S55-S75. https://doi.org/DOI: 10.1017/S0031182000086121

Westheimer, J., \& Kahne, J. (2004). What Kind of Citizen? The Politics of Educating for Democracy. American Educational Research Journal, 41(2), 237-269.

doi:10.3102/00028312041002237

WHO. (2019). Global Preparedness Monitoring Board. A world at risk: annual report on global preparedness for health emergencies. Geneva, $\mathrm{CH}$.

Wilkinson, I. (2001). Social Theories of Risk Perception: At Once Indispensable and Insufficient. Current Sociology, 49(1), 1-22. doi:10.1177/0011392101049001002

Wong, D. \& Pugh, K. (2001). Learning science: a deweyan perspective. Journal of Research in Science Teaching, 38(3), 317-336.

Wu, T., Perrings, C., Kinzig, A., Collins, J. P., Minteer, B. A., \& Daszak, P. (2017). Economic growth, urbanization, globalization, and the risks of emerging infectious diseases in China: A review. Ambio, 46(1), 18-29. doi:10.1007/s13280-016-0809-2 